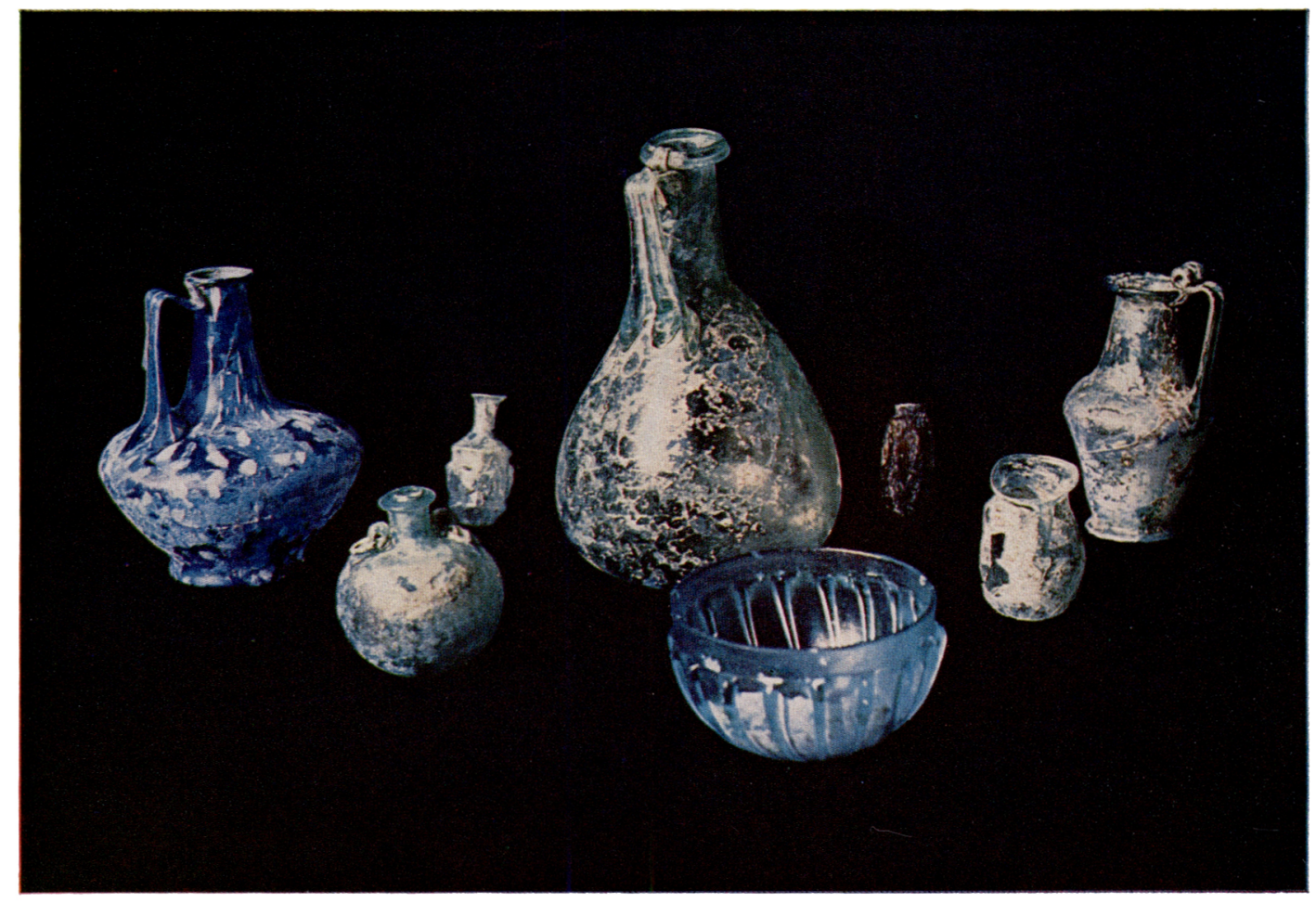

A ROMAN CHAMBER TOMB ON THE S.E. SLOPES OF MONASTERIAKI KEPHALA, KNOSSOS from left to right: $17\left(\mathrm{G}_{15}\right) ; 60\left(\mathrm{G}_{2}\right) ; 62(\mathrm{G} 18) ; 18\left(\mathrm{G}_{52}\right) ; 1\left(\mathrm{G}_{16}\right) ; 65\left(\mathrm{G}_{5} 6\right) ; 59\left(\mathrm{G}_{3}\right) ; 19\left(\mathrm{G}_{11}\right)$ 


\title{
THE ANNUAL
}

\section{OF THE}

\section{BRITISH SGHOOL AT ATHENS}

\author{
No. 77
}

1982

\section{THE BRITISH SCHOOL AT ATHENS}

31-34 GORDON SQUARE, LONDON WCIH OPY

Published by the Managing Committee 
(C) The Managing Commitee, British School of Archaeology at Athens 1982

Printed in Greal Britain at the University Press, Oxford by Eric Buckley

Printer to the University 


\title{
BRITISH SCHOOL AT ATHENS
}

\author{
3 I-34 GORDON SQUARE, \\ LONDON, WCIH OPY
}

ANNUAL OF THE BRITISH SCHOOL AT ATHENS: The following are in print, available from the above address:

\begin{tabular}{|c|c|c|c|}
\hline Volume $53 / 54\left(195^{8 / 9}\right)$ & $£ .15 \cdot 00$ & Volume 69 (1974) & $£^{16 \cdot 00}$ \\
\hline Volume 60 ( 1965$)$ & $£ 15.00$ & Volume 70 (I975) & $£^{20} \cdot 00$ \\
\hline Volume 6i ( 1966$)$ & $E_{1} 5^{\circ} 00$ & Volume 7 I $(1976)$ & $£^{20 \cdot 00}$ \\
\hline Volume 62 (1967) & $\mathscr{E}_{15} 5^{\circ 00}$ & Volume 72 (1977) & $£^{20} \cdot 00$ \\
\hline Volume 63 (i968) & $£ 15.00$ & Volume 73 (1978) & $£^{20} \cdot 00$ \\
\hline Volume 64 (1969) & $\mathscr{E}^{\mathrm{I}} 5^{\circ} \mathrm{OO}$ & Volume 74 (1979) & $£ 30 \cdot 00$ \\
\hline Volume 65 (1970) & $£$ i 5.00 & Volume 75 ( $\left.19^{80}\right)$ & $£ 3^{\circ} \cdot 00$ \\
\hline Volume 66 (I97I) & $\mathcal{E}_{15} 5.00$ & Volume $76(\mathrm{I} 98 \mathrm{I})$ & $\{30 \cdot 00$ \\
\hline Volume 67 (1972) & $E_{15} \cdot 00$ & Index Volumes $33^{-4}$ & $f^{1} \cdot 50$ \\
\hline Volume 68 (1973) & E. 15.00 & Index Volumes $49^{-68}$ & $\mathscr{E} 75^{\circ}$ \\
\hline
\end{tabular}

Volumes $\mathrm{I}-4 \mathrm{O}$ of the $A \mathcal{N N} U A L$ and Index Volumes $\mathrm{I}-32$ have been reprinted, available from: Kraus Reprints, FL949 I Nendeln, Liechtenstein.

SUPPLEMENTARY VOLUMES as follows available from Thames \& Hudson Ltd., 44 Glockhouse Road, Farnborough, Hants.

No. 3 The Technique of Greek Sculpture (Adam, I966)

No. 4 Tocra 1963-5: The Archaic Deposits I (Boardman and Hayes, 1966)

No. 5 Saliagos: Neolithic Settlement (Evans and Renfrew, r968)

No. 6 Chios: Greek Emporio (Boardman, 1967)

No. 7 Myrtos: Early Bronze Age Settlement (Warren, 1972)

No. 8 Knossos: The Sanctuary of Demeter (Coldstream, 1973)

No. 9 The Finlay Papers: A Catalogue (J. M. Hussey, 1973)

No. 10 Tocra: The Archaic Deposits II, and Later Deposits (Boardman and Hayes, 1974)

No. I I Lefkandi I: The Iron Age (Popham, Sackett, and Themelis) Plates (1979)

Text ( 1980$)$

No. 12 Excavations at Mycenae 1939-1955 (ed. French, 1980)

No. I3 The Bronze Age Palace at Knossos: Plan and Sections (Hood and Taylor, $198 \mathrm{I}$ )

No. I4 An Archaeological Survey of the Knossos Area (Hood and Smyth, I98I)

No. 15 Prehistoric Emporio and Ayio Gala I (Hood, I981)

$£ 20 \cdot 00$

$£ 25 \cdot 00$

$£ 25.00$

$£ 25.00$

$£ 25.00$

E16.00

$£ 16.00$

$£ 25 \cdot 00$

$£ 27.00$

$£ 4^{6.00}$

$£ 27.00$

Ei $4^{\circ 00}$

Erg.oo

$£ 70 \cdot 00$

A L SO

No. 16 Prehistoric Emporio and Ayio Gala II (Hood, 1982)

$662 \cdot 5^{\circ}$

In preparation: Phylakopi: The Shrine

Lefkandi II: The Bronze Age

The Unexplored Mansion, Knossos 


\section{THE BRITISH SCHOOL AT ATHENS}

Patron: H.R.H. The Prince Philip, Duke of Edinburgh, k.g., k.t., g.b.e.

Director

Dr. H. W. Catling, o.B.E., M.A., D.PHil., F.s.A., Joint Editor of the Annual

\section{MANAGING COMMITTEE}

Professor P. M. Warren, B.A., M.A., Ph.D., F.S.A., Chairman

Professor Bernard Ashmole, c.B.e., m.c., M.A., B.litt., f.B.A., Trustee

Professor R. M. CoOK, M.A., F.B.A., Trustee

Professor John Boardman, M.A., F.B.A., F.s.A., Trustee

H.B.M. Ambassador at Athens, Vice-President

Sir Clifford Norton, K.c.m.G., c.v.o., M.A., Vice-President

A. H. S. Megaw, EsQ., C.B.E., M.A., F.S.A., Vice-President

Dr. M. F. B. Frtch, D.LitT, hon. F.B.A., F.S.A., Vice-President

Dr. W. H. Plommer, M.A., D.PhIl., Ph.D.

Appointed by the University of Cambridge

Professor J. N. Coldstream, m.A., F.B.A., F.s.A.

Appointed by the University of London

DR. J. Coulton, M.A., PH.D.

Appointed by the University of Oxford

Revd. Professor W. Meany, M.A., PH.D., D.D.

Appointed by the National University of Ireland

Professor F. G. B. Millar, M.A., D.Phil., F.B.A.

Appointed by the British Academy

B. F. Cook, EsQ., M.A., F.s.A.

Appointed by the British Museum

Dr. R. L. N. Barber, M.A., Ph.D.

Professor A. A. M. Bryer, M.A., D.PHil., F.S.A.

Dr. E. B. French, M.A., Ph.D., F.S.A.

DR. R. A. Higgins, M.A., LitT.D., F.B.A., F.s.A.

Dr. C. B. MeE, M.A., PH.D.

Dr. A. J. N. W. Prag, M.A., D.PhIl.

Professor A. C. Renfrew, M.A., Ph.D., Sc.D., F.B.A., F.s.A.

Professor A. M. SNodgrass, M.A., D.Phil.

Professor R. A. Tomlinson, M.A., F.S.A., Joint Editor of the Annual

Representatives of the Students

D. G. J. Shipley, Eso., m.A.

P. J. Callaghan, Esq., M.A.

Secretary: Mrs. S. E. Waywell, B.A., PH.D., 31-34 Gordon Square, London waih oPy

Treasurer: C. R. G. Stevens, EsQ., Woodgate, South Munstead Lane, Golalming, Surrey gu8 4 AG 


\section{TABLE OF CONTENTS}

i. D. Blackman and K. Branigan. The Excavation of an Early Minoan Tholos Tomb at Ayia Kyriaki, Ayiofarango, Southern Crete (Plates I-2)

2. H. W. Catling, C. Ridley, J. Carington Smith, D. Smyth, and A. W. Dunn. Knossos 1978: Roman Finds at the Venezeleion (Plate 3)

3. W. G. Cavanagh and R. R. Laxton. Corbelled Vaulting in the Late Minoan Tholos Tombs of Crete (Plate 4)

4. P. S. Derow and W. G. Forrest. An Inscription from Chios (Plate 5)

5. D. F. Easton. The Schliemann Papers . . . . . . . 93

6. T. W. Gallant. Agricultural Systems, Land Tenure, and the Reforms of Solon.

7. R. Garland. A First Catalogue of Attic Peribolos Tombs . . I 125

8. R. HäGg and F. Sieurin. On the Origin of the Wooden Coffin in Late Bronze Age Crete

9. R. Janko. Frankish and French Coins from Ayios Stephanos, Laconia

io. J. Ellis Jones. Another Eleusinian Kernos from Laureion (Plate 6)

I 87

I I. E. Moignard. The Acheloos Painter and Relations (Plates 7-14)

I 9 I

I2. M. R. Popham, E. Touloupa, and L. H. Sagketr. Further Excavation of the Toumba Cemetery at Lefkandi, I 98 I (Plates I 5-34)

13. D. S. Reese. Recent and Fossil Shells from Tomb xviii, Gypsades cemetery, Knossos, Crete

14. N. V. Sekunda. A Bronze Horse-frontlet from Vrokastro, Crete

15. J. Carington Smith. A Roman Chamber Tomb on the South-east slopes of Monasteriaki Kephala, Knossos. (Frontispiece and Plates 35-44) 